\title{
Proximity Approach as an Option in Global Markets*
}

\author{
Marco Bordoli**
}

\begin{abstract}
CRAI was founded in 1973 by a small group of food retailers that joined forces to set up the Commissionarie Riunite Alta Italia (C.R.A.I), which later on turned into Commissionarie Riunite Alimentaristi Italiani. The company as a buying group has become in such a short time a key player in the Italian food retail sector developing an Italian retail business model based on the 'proximity store' as option to compete in a global market.
\end{abstract}

Keywords: Retailing; Proximity Stores; Buying Group; Private Label; MarketDriven Management; Over-Supply

\section{CRAI and the Proximity Store Format}

When in 1973 'Commissionarie Riunite Alimentaristi Italiani' (CRAI) was founded, Italy was a Country where a multinational corporation like Unilever, in order to sell margarine and processed cheese, had to visit daily over 30,000 shops throughout the domestic territory employing a sales force amounting to 150 people, equipped with delivery trucks, responsible for taking the orders, issuing the proforma invoices, delivering the goods, and collecting the payments. It goes without saying that it was a very smart move on their part when shoppers decided to form buying groups that in just one purchasing centre could make orders gaining better prices for them but reducing strongly the manufacturers' selling cost.

And that is exactly what CRAI is all about: a widespread sales network constituted by independent family-owned food retail stores in both large urban areas and rural areas able to meet a wide array of consumers' needs thanks to an assortment ranging from food and beverages to over-the-counter (OTC) drugs.

CRAI's mission is bringing together independent business owners so that they can start cooperating with each other. This is also the reason why CRAI as a buying group has become in such a short time a new key player in the Italian food retail sector. Nowadays, CRAI is able to compete against 'voluntary unions' (aggregations in marketing channels that combine one or more wholesale companies with retailers) as well as against national and international chain stores. Since then, buying groups and voluntary chains have been classified as large-scale organized distribution and chain stores as large-scale distribution. While these latter

\footnotetext{
* Invited Article

** CEO, CRAI (mbordoli@ crai.org)

Edited by: ISTEI - University of Milan-Bicocca

ISSN: 1593-0319

Bordoli, M. (2015). Proximity Approach as an Option in Global Markets, Symphonya. Emerging Issues in Management (symphonya.unimib.it), 5, 36-40.
} 
ones have opted for large-area self-service stores evolving their format from supermarket to hypermarket or superstore, large-scale organized retailers have instead privileged the format of traditional shops and little self-services (e.g. convenience store, supermarket 400 and $2500 \mathrm{sm}$.). Even though large-scale retailing is the predominant business model throughout the world, organized retailing has become particularly relevant in Italy as a way of supporting domestic food producers through promotion of Made in Italy agricultural products and foodstuffs. In this regard, CRAI has developed a unique Italian retail business model that might represent an alternative option to other current models. When we take a look at other Countries and compare them to Italy, we can make the following distinctions:

- The French retail business model prioritizes a centralized organization based on the 'hypermarket' format;

- The German model instead privileges efficient formats such as 'discount stores and cash\&carry;'

- The English one, being more pragmatic, relies more on the 'convenience store' format.

- Finally, the Italian model, formed by a network of small-scale retail stores is based on the 'proximity store' format.

The development of this unique business retail model, which has become the main feature of the CRAI group, has been made possible thanks to the clever and hard work of all CRAI store owners who have been able to build a strong and longlasting relationship with the consumers - CRAI's retail network comprises 3,200 stores, whose size ranges from 100 and 400 square meters, located in more than 1,000 geographical areas -, and last but not least, thanks to our assortment based primarily on fresh products like vegetables, fruit, cheese, meat, and bakery.

\section{Private Label Portfolio}

Today, CRAI is proud to offer a wide range of both mainstream and premium private label products including its own assortment of PDO wines carefully selected and packed by CRAI according to a rigorous quality control and traceability process.

Thanks to its business development policy and genuine products, since 2001, we at CRAI have been able to advertise our brand with the claim 'Genuinamente italiano' (Genuinely Italian), which has later on evolved into our current slogan 'Nel cuore dell'Italia' (In the heart of Italy). CRAI's customers can rest assured we will live up to our promise because they can experience the genuine and superior quality of our products and the modus operandi of our highly skilled and trained personnel on a day-to-day basis.

As a result of our strategic planning, we managed to expand our operations overseas. In this regard, CRAI has become the biggest chain of groceries in Malta able to bring 'The Italian taste at your home.'

In addition, we have developed an effective positioning strategy for our grocery stores so that the food retailer would not just simply be anymore an intermediate that buys and sells groceries to make a profit, but also a key player who needs to implement a marketing plan consistent with its brand positioning aimed at building 
durable values for the company's stakeholders.

With this goal in mind, CRAI has evolved its buying group mission both in terms of legal status and business alliance. With regard to the legal status, after 30 years of pure cooperative, CRAI create a capital limited company (CRAI SECOM) that owns the trade mark CRAI and coordinates commercial activities (procurement, marketing, etc.) on national base.

Figure 1: CRAI Private Label Portfolio

Private Label: owned Brands

\begin{tabular}{|l|l|}
\hline VALUE FOR MONEY & 1.130 \\
\hline PREMIUM & 93 \\
\hline SELECTION OF ITALIAN WINE & \\
\hline FAIRTRADE & \\
\hline BIOLOGICAL & 137 \\
\hline GUARANTEE ITALIAN TRACEABILITY & 137 \\
\hline HEALTHY LIVING & 10 \\
\hline PERSONAL \& SKIN CARE & 23 \\
\hline BASIC / CHEAPEST PRICE & 119 \\
\hline
\end{tabular}

Figure 2: CRAI Company Structure

\section{The Company Structure}

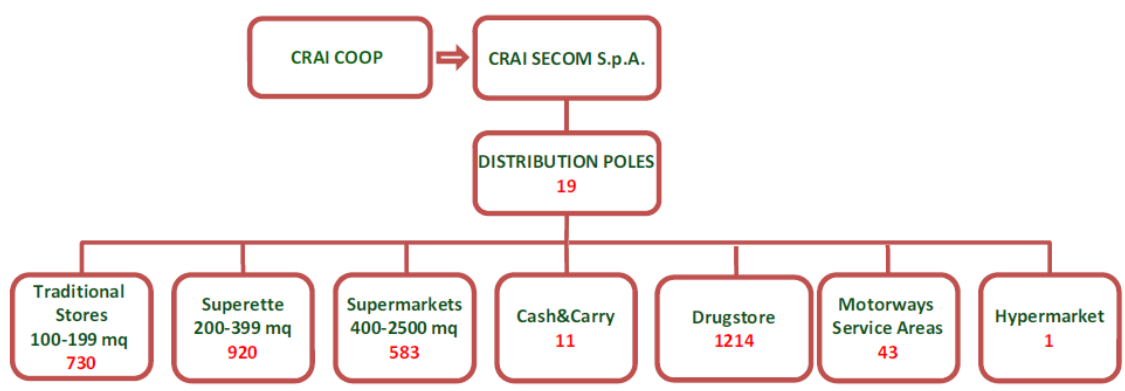

Extremely important in terms of competitiveness, it has been the implementation of an alliance policy through long-term agreements with other retailers, whose brand positioning was not overlapping with that of CRAI, but that could guarantee an attractive multi channel offering and extensive national coverage.

As a consequence, to its new hybrid approach, CRAI has been able to attract new shareholders, which, together with an ambitious marketing plan, will help strengthen the company's growth in the years to come despite the current economic turmoil and volatile market. Furthermore, CRAI's business development model has led to a dramatic increase in the sales of specific product categories within the CRAI's assortment. For instance, the categories 'Home and personal care', 
'Perfumery', and 'Pet food store' (total $\mathrm{ms}$ in drug 25,5\%), have played a pivotal role in the excellent Italian market performance of the Group.

Figure 3: CRAI Performance

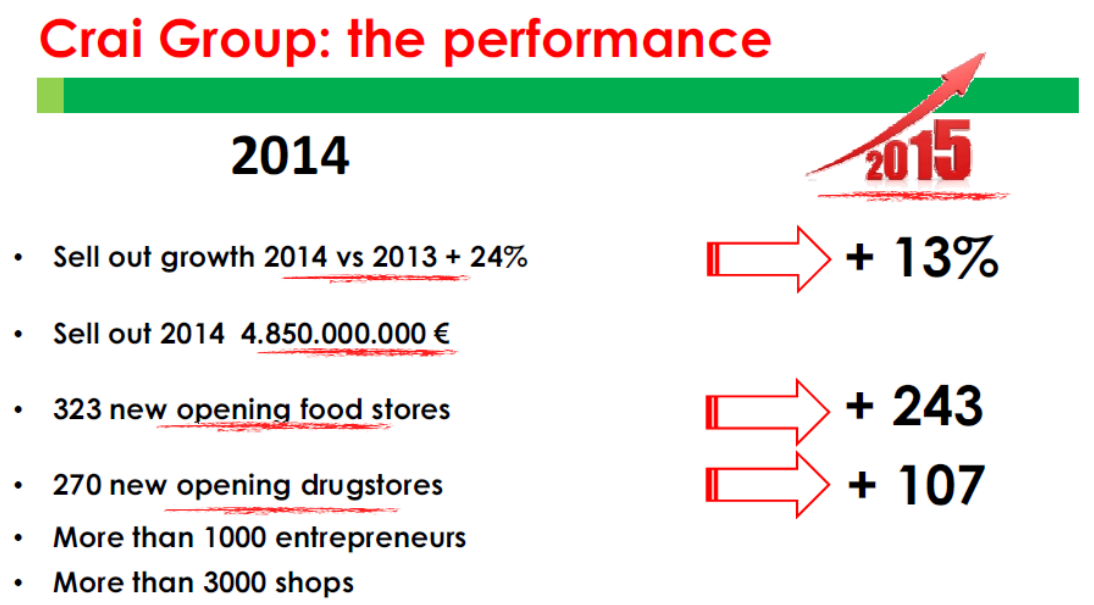

\section{Future Perspectives}

If we can only think about how many new food categories could become part of our assortment and be launched through our model of proximity marketing, we might as well predict that these would become bestseller products. Obviously, this could only be achieved if we were able to maintain and implement a strong synergy among CRAI stakeholders in all the key aspects of food retailing, such as customer care, sales and purchasing, logistics, format development, real estate solutions, advertising, internet and research \& development.

Strategic planning, by definition, is a decisional process about what is most important to achieve organizational success. Since most of this process is based on parallel thinking and brainstorming, which are key factors of creativity in business, it is possible to hypothesize that in the future CRAI grocery stores might evolve into stores offering exclusively private label food products within a specific price range, or specialty and natural foods. Nonetheless, our business development principles shall always be consistent with the proximity approach that was originally envisioned by CRAI's founders, reason why CRAI in 2016 was awarded with the prestigious Italian prize 'Eccellenza nel Commercio' by the President of the Italian Republic Sergio Mattarella during the 70th anniversary of Italian Trade Association Confcommercio, which coincided with the 70th anniversary celebrations of the Italian Republic.

\section{Bibliography}

Barros, C.P. (2006). Efficiency Measurement Among Hypermarkets And Supermarkets And The Identification Of The Efficiency Drivers: A Case Study, International Journal of Retail \& Distribution Management, 34 (2), 135-154.

http://dx.doi.org/10.1108/00251740810890195 
Basker, E., Klimek, S., \& Hoang Van, P. (2012). Supersize It: The Growth of Retail Chains and the Rise of the 'Big-Box' Store, Journal of Economics \& Management Strategy, 21 (3), 541-582.

http://dx.doi.org/10.1111/j.1530-9134.2012.00339.x

Brondoni, S.M. (2015). Global Networks, Outside-In Capabilities and Smart Innovation, Symphonya. Emerging Issues in Management (symphonya.unimib.it), 1, 6-21.

http://dx.doi.org/10.4468/2015.1.02brondoni

Brondoni, S.M., \& Musso, F. (2010). Ouverture de 'Marketing Channels and Global Markets', Symphonya. Emerging Issues in Management (symphonya.unimib.it), 1, 1-6.

http://dx.doi.org/10.4468/2010.1.01ouverture

Ferniea, J., \& Stainesb, H. (2001). Towards An Understanding of European Grocery Supply Chains, Journal of Retailing and Consumer Services, 8 (1), 29-36.

http://dx.doi.org/10.1016/S0969-6989(00)00002-3

Gnecchi, F. (2009). Market-Driven Management, Market Space and Value Proposition, Symphonya. Emerging Issues in Management (symphonya.unimib.it), 2, 33-45.

http://dx.doi.org/10.4468/2009.2.04gnecchi

Goldman, A., \& Hino, H. (2005). Supermarkets vs. Traditional Retail Stores: Diagnosing the Barriers to Supermarkets' Market Share Growth in an Ethnic Minority Community, Journal of Retailing and Consumer Services, 12 (4), 273-284.

http://dx.doi.org/10.1016/j.jretconser.2004.10.002v

Riboldazzi, S. (2005). Global Retailers and Competitive Customer Value, Symphonya. Emerging Issue in Management (symphonya.unimib.it), 2, 77-87.

http://dx.doi.org/10.4468/2005.2.07riboldazzi

Riboldazzi, S. (2010). Retail Policies in the Global Gasoline Market, Symphonya. Emerging Issues in Management (symphonya.unimib.it), 1, 86-101.

http://dx.doi.org/10.4468/2010.1.09riboldazzi

Uusitalo, O. (2001). Consumer Perceptions of Grocery Retail Formats and Brands, International Journal of Retail \& Distribution Management, 29 (5), 214-225.

http://dx.doi.org/10.1108/09590550110390995

Verhetsel, A. (2005). Effects of Neighbourhood Characteristics on Store Performance Supermarkets Versus Hypermarkets, Journal of Retailing and Consumer Services, 12 (2), 141-150.

http://dx.doi.org/10.1016/j.jretconser.2004.11.004 